\title{
TAXATION AND ECONOMIC DEVELOPMENT IN THE FORMER COMMUNIST BLOC. A PANEL DATA APPROACH
}

\author{
Andrei lonut Husman \\ The Bucharest University of Economic Studies, Bucharest, Romania \\ husman.andrei@yahoo.com
}

\begin{abstract}
Taxation and its implications are an increasingly debated topic since taxation is a very important tool for the governments of all countries in controlling public finances. At the same time, taxation regulates in one way or another the wealth of a country and, implicitly, of its citizens. In this sense, through this paper we aim to analyse the impact of taxation on economic growth felt by citizens, and our attention has been focused on EU Member States from the former Communist Bloc: Hungary, Poland, Romania, Slovakia and Slovenia. To measure the economic growth felt by the citizens, the best proxy is GDP per capita. Regarding taxation, we resorted to the use the revenues registered from personal income tax, corporate income tax and VAT. The chosen countries share a similar past and had in one way or another the same starting point in the 1990s. These countries are also from the same geographical region (Central and East European countries) and have to some extent comparable economies. Furthermore, we performed an econometric analysis with panel data for the period 2003-2018. The results thus obtained from the econometric tests indicated by an econometric model with random effects showed a direct positive relationship between the dependent variable and the independent variables. The coefficients obtained were statistically significant in the case of independent variables represented by the revenues from personal income tax and VAT, while the coefficient related to revenues from corporate income tax proved to be statistically insignificant.
\end{abstract}

Keywords: taxation, economic development, Communist Bloc, panel data

JEL classification: H20, H31, C33

\section{Introduction}

We are facing a context where there is a continuous transformation in all the economies and the subject of taxation is a matter of interest for both academics and practitioners. Despite the fact that we are discussing about current EU Member States, each country has the freedom to choose and build its tax system.

As for the EU Member States that were part of the former Communist Bloc, they have a gap in terms of the development of economies in the capitalist era. Compared to other Member States, they were under Soviet occupation until the 1990s and after this period, these countries started almost from scratch in building their capitalist economies. Therefore, all these states had a common starting point, but the level of development was in one way or another different in the post-communist period.

However, the states in question agreed with the rigors, but also with the benefits of capitalist economies and, in turn, became EU member states. Thus, through this paper we aimed to analyse the relationship between the main elements of taxation and economic growth felt at the level of citizens (best expressed by GDP per capita).

Thus, starting from the specific econometric methodologies, as well as from the results presented in the specialized literature, we performed an econometric analysis in which we estimated econometric models using panel data with the help of State software. The tax 
elements included in the econometric model were represented by the revenues from Corporate income tax ("CIT"), Personal income tax ("PIT") and Value added tax ("VAT"). Further, in the next chapter, we will present a brief synthesis of the main results identified in the literature, and in Chapter 3, the econometric results will be presented and debated.

\section{Literature review}

In the recent period, the importance of taxation, as well as its effects on economic growth have become an increasingly debated topic in the literature. A variety of studies focus on the effects of taxation on the main elements of the economy, with an emphasis on economic growth and several studies involve statistical/econometric analysis.

This approach on carrying out econometric studies on the relation between the fiscal elements and the economy is an older one, but in the following, we will refer to some more recent and relevant studies for the subject approached in this paper.

Through a linear regression with panel-corrected standard errors, Dolenc \& Laporsek (2010) analyzed the PIT impact on the employment growth for EU27 Member States in the period 1999-2008 and. Their results showed a negative relationship between those two elements and they found that a decrease in PIT revenues could lead to an increase in the demand on labour and employment.

Szarowská (2013) used a panel regression and Pairwise Granger Causality Tests in order to analyse the effects of changes in tax burden on economic growth. The results on the 24 EU Member States showed a negative effect of taxes on labour on economic growth, while for consumption taxes the effect found was a positive one.

Stoilova \& Patonov (2012) found a significant positive effect of PIT and SSC revenues on the long-term economic growth, by using a similar econometric methodology.

The literature also offers us certain studies on the case of Romania. By using a Vector Autoregressive model based on quarterly data, Bazgan (2018) found that a positive change in the indirect taxes structure would have a strong positive outcome on the economic growth over a medium-term period. Meanwhile, a positive change in the direct taxes structure would have a negative outcome on short-term and following the medium-term the impact is returning to a positive one. By the means of regression, Surugiu and Surugiu (2018a) found a negative impact of distortionary taxes on economic growth and a positive one of nondistortionary taxes for the period 1991-2013 in the case of Romania. Further, based on a similar study, but using only direct (CIT and PIT) and indirect taxes (VAT), Surugiu and Surugiu (2018b) only use the direct taxes (CIT and PIT) and indirect taxes (VAT) found that both types of taxes have a significant positive impact on the economic growth in the period 1995-2014.

Further, Hakim (2020) used a panel with 51 countries and the dynamic panel generalized method of moments' estimation in order to investigate the impact of direct and indirect taxes on economic growth for the period 1992-2016. The related results showed that direct taxes have a significant negative impact on the economic growth, while indirect directs have positive but insignificant impact. Lymonova (2019) and Alfo et al. (2020) obtained similar results. Through a Granger causality analysis, Vatavu et al. (2019) found that taxes support economic growth. Durovic-Todorovic et al. (2019), Dackehag \& Hansson (2012), Topal (2019), Bakari et al. (2019), Andrašić et al. (2019) and Kalaš et al. (2018) obtained similar results.

Therefore, a variety of studies on this topic is found in the specialized literature, including studies containing econometric analysis. 


\section{Econometric results}

As mentioned, within this paper we carried out an econometric analysis by using panel data. The econometric models were obtained in Stata software. Therefore, in the following we present the methodology used and the results obtained.

\subsection{The methodologies used}

The equation that was the basis of the obtained models is the following:

$G D P p c \_p_{i t}=\beta_{0}+\beta_{1} \times C I T \_p_{i t}+\beta_{2} \times P I T \_p_{i t}+\beta_{3} \times V A T \_p_{i t}+u_{i t}$

Where:

- GDPpc_p = the Gross domestic product per capita expressed as growth percentages from previous year;

- $\quad$ CIT_ $p=$ the Corporate income tax expressed as growth percentages year by year;

- $\quad$ PIT_ $p=$ the Personal income tax expressed as growth percentages year by year;

- VAT_p = the Value added tax expressed as growth percentages year by year;

- $\beta_{0}=$ the constant;

- $\quad \beta_{1}-\beta_{3}=$ the coefficients for each independent variable;

- $\mathrm{u}=$ the error term;

- $\quad \mathrm{i}=$ the country;

- $t=$ the time (year).

Our analysis focuses on the period 2003-2018, and the necessary data were extracted from the Eurostat database. The countries subject to the econometric analysis were Hungary, Poland, Romania, Slovakia and Slovenia.

\subsection{Testing for data stationarity}

Before estimating econometric models, we tested the dataset used for unit roots/stationarity. We run the Levin-Lin-Chu unit-root test available in Stata for all the dataset used by using the command xtunitroot. The output for each dataset is presented in tables 1-4 below.

Table 1: The output of unit roots test for GDPpc p p

\begin{tabular}{|c|c|c|}
\hline \multicolumn{3}{|l|}{ xtunitroot IIc GDPpc_p } \\
\hline \multicolumn{3}{|c|}{ Levin-Lin-Chu unit-root test for GDPpc_p } \\
\hline Ho: Panels contain unit roots & \multicolumn{2}{|c|}{ Number of panels $=5$} \\
\hline Ha: Panels are stationary & \multicolumn{2}{|c|}{ Number of periods $=16$} \\
\hline \multicolumn{3}{|l|}{ AR parameters: Common } \\
\hline \multicolumn{3}{|l|}{ Panel means: Included } \\
\hline \multicolumn{3}{|l|}{ Time trend: Not included } \\
\hline \multicolumn{3}{|l|}{ ADF regressions: 1 lag } \\
\hline \multicolumn{3}{|c|}{ LR variance: Bartlett kernel, 8.00 lags average (chosen by LLC) } \\
\hline & Statistic & $p$-value \\
\hline Unadjusted t & -5.4243 & \multirow{2}{*}{0.0031} \\
\hline Adjusted $\mathrm{t}$ & -2.7324 & \\
\hline
\end{tabular}

Source: own processing using Stata 
Table 2: The output of unit roots test for CIT $p$

\begin{tabular}{|c|c|c|}
\hline xtunitroot IIc CIT_p & & \\
\hline Levin-Lin-Chu unit-root test & T $\mathbf{p}$ & \\
\hline Ho: Panels contain unit roots & Number & panels $=5$ \\
\hline Ha: Panels are stationary & Number & eriods $=16$ \\
\hline AR parameters: Common & & \\
\hline Panel means: Included & & \\
\hline Time trend: Not included & & \\
\hline ADF regressions: $1 \mathrm{lag}$ & & \\
\hline LR variance: Bartlett kernel, 8 & avera & sen by LLC) \\
\hline & Statistic & D-value \\
\hline Unadjusted t & -5.7263 & 0.0026 \\
\hline Adiusted t & -2.7985 & \\
\hline
\end{tabular}

Source: own processing using Stata

Table 3: The output of unit roots test for PIT $p$

\begin{tabular}{|c|c|c|}
\hline \multicolumn{3}{|l|}{ xtunitroot IIc PIT_p } \\
\hline \multicolumn{3}{|c|}{ Levin-Lin-Chu unit-root test for PIT_p } \\
\hline Ho: Panels contain unit roots & \multicolumn{2}{|c|}{ Number of panels $=5$} \\
\hline Ha: Panels are stationary & \multicolumn{2}{|c|}{ Number of periods $=16$} \\
\hline \multicolumn{3}{|l|}{ AR parameters: Common } \\
\hline \multicolumn{3}{|l|}{ Panel means: Included } \\
\hline \multicolumn{3}{|l|}{ Time trend: Not included } \\
\hline \multicolumn{3}{|l|}{ ADF regressions: $1 \mathrm{lag}$} \\
\hline \multicolumn{3}{|c|}{ LR variance: Bartlett kernel, 8.00 lags average (chosen by LLC) } \\
\hline & Statistic & p-value \\
\hline Unadjusted $\mathrm{t}$ & -5.6625 & \multirow{2}{*}{0.0062} \\
\hline Adjusted $\mathrm{t}$ & -2.5025 & \\
\hline
\end{tabular}

Source: own processing using Stata

Table 4: The output of unit roots test for VAT_p

\begin{tabular}{|c|c|c|}
\hline xtunitroot IIc VAT $p$ & & \\
\hline Levin-Lin-Chu unit-root tes & AT $p$ & \\
\hline Ho: Panels contain unit roots & Number & oanels $=5$ \\
\hline Ha: Panels are stationary & Number & eriods $=16$ \\
\hline AR parameters: Common & & \\
\hline Panel means: Included & & \\
\hline Time trend: Not included & & \\
\hline ADF regressions: 1 lag & & \\
\hline LR variance: Bartlett kernel, 8 & gs average & sen by LLC) \\
\hline & Statistic & D-value \\
\hline Unadjusted t & -8.1629 & ก nח0n \\
\hline Adiusted t & -5.0728 & \\
\hline
\end{tabular}

Source: own processing using Stata

As we can be observed in the above outputs, the p-values associated with the unit-roots tests are lower than the 5\% significance threshold for all the dataset. Therefore, we rejected the null hypothesis that states the presence of unit-roots, which means that all the variables 
are stationary. This result may be caused by the use of data in the form of growth rates (compared to the previous years).

\subsection{The fixed effects model}

Initial econometric tests showed that the individual effects are not negligible. Consequently, we proceed to estimate econometric models with panel data. The first model estimated was the model with fixed effects ("FE model"). We use the function xtreg from Stata and the output resulted is presented in Table 5 below.

Table 5: The output of FE model estimation

\begin{tabular}{|c|c|c|c|c|c|c|}
\hline \multicolumn{7}{|l|}{ xtreg $G L$} \\
\hline \multicolumn{4}{|c|}{ Group variable: country } & \multicolumn{3}{|c|}{ Number of obs $=80$} \\
\hline \multirow{2}{*}{\multicolumn{4}{|c|}{ R-square overall $=0.7834$}} & \multicolumn{3}{|c|}{ Number of groups $=5$} \\
\hline & & & & Obs pe & $r$ group $=16$ & \\
\hline \multicolumn{7}{|c|}{$F(3,72)=85.22$} \\
\hline GDPpc_p & Coef. & Std. Err. & $\mathrm{t}$ & $P>|t|$ & {$[95 \%$ Con } & f. Interval] \\
\hline CIT p & 0.0596401 & 0.0298035 & 2.00 & 0.049 & 0.000228 & 0.1190523 \\
\hline PIT_p & 0.2449891 & 0.0454647 & 5.39 & 0.000 & 0.1543568 & 0.3356214 \\
\hline VAT_p $p$ & 0.3710471 & 0.0462954 & 8.01 & 0.000 & 0.278759 & 0.4633352 \\
\hline cons & 0.0188101 & 0.0052123 & 3.61 & 0.001 & 0.0084195 & 0.0292006 \\
\hline
\end{tabular}

Source: own processing using Stata

The output show that the registered value of Prob (F) fulfils the conditions to conclude that the model is valid. Its value is greater than $0.05(5 \%)$ and all the coefficients different from zero. The validity is also shown through the R-square value (that are over $50 \%$ ).

The values of associated probability for each independent variable are greater than the threshold of 0.05 . Therefore, we can assume that all the independent variables have a significant influence on the dependent variable. This is also reinforced by the t-values registered.

\subsection{The random effects model}

Further, we estimate the model with random effects ("RE model") by using the same function (xtreg). The output of RE model estimation is presented in Table 6 below:

Table 6: The output of RE model estimation

\begin{tabular}{|c|c|c|c|c|c|c|}
\hline \multicolumn{7}{|c|}{$\begin{array}{l}x t r e g \text { GDPpc_p CIT_p PIT_p VAT_p, re } \\
\text { Random-effects GLS regression }\end{array}$} \\
\hline \multicolumn{4}{|c|}{ Group variable: country } & \multicolumn{3}{|c|}{ Number of obs $=80$} \\
\hline \multirow{2}{*}{\multicolumn{4}{|c|}{ R-square overall $=0.7835$}} & \multicolumn{3}{|c|}{ Number of groups $=5$} \\
\hline & & & & \multicolumn{3}{|c|}{ Obs per group $=16$} \\
\hline \multicolumn{7}{|c|}{ Wald chi2 $2(3)=275.03$} \\
\hline GDPpc_p & Coef. & Std. Err. & $\mathrm{t}$ & $P>|t|$ & {$[95 \%$ Con } & Interval] \\
\hline CIT_p & 0.0558396 & 0.0300782 & 1.86 & 0.063 & -0.0031126 & 0.11479 \\
\hline PIT_p & 0.2554725 & 0.0454281 & 5.62 & 0.000 & 0.166435 & 0.3445099 \\
\hline VAT $p$ & 0.3835876 & 0.0466186 & 8.23 & 0.000 & 0.2922167 & 0.4749585 \\
\hline cons & 0.0175193 & 0.0052575 & 3.33 & 0.001 & 0.0072148 & 0.0278238 \\
\hline
\end{tabular}

Source: own processing using Stata 
The results from the RE model are quite similar to the ones from FE model. The main difference is that the independent variable is greater than the threshold value of 0.05 and is not significant from a statistical point of view. The rest of the comments mentioned for the FE model are also applicable in the case of RE model.

\subsection{Choosing the most appropriate model}

Further, in our analysis it was necessary to decide which model fits better. Consequently, in order to decide between the FE model and RE model, we use the Hausman test and the results are presented in Table 7 below.

Table 7: The output of Hausman test

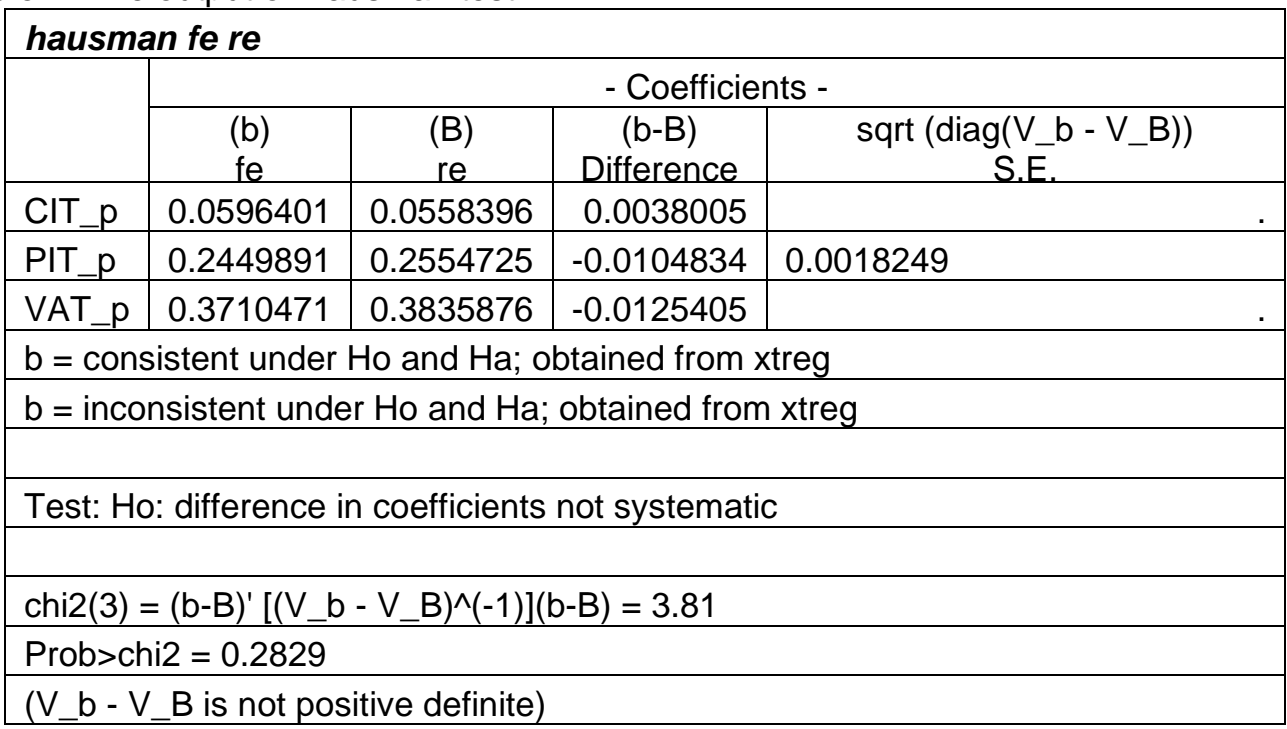

Source: own processing using Stata

According to these results, since the probability associated to the Hausman test is over the threshold of 0.05 , the use of RE model would be more appropriate (Baltagi, 2005).

\subsection{Testing for serial correlation}

An additional test performed in our analysis is related to serial correlation. Thus, in order to the autocorrelation in panel data we used the Wooldridge test. This test has as null hypothesis that states there is no first-order autocorrelation within the dataset. By using the command xtserial in Stata we run this test and the results are presented in table 8 below.

Table 8: The output of Wooldridge test for autocorrelation in panel data

\begin{tabular}{|c|}
\hline $\boldsymbol{x}$ Sserial GDPpc_p CIT_p PIT_p VAT_p \\
\hline Wooldridge test for autocorrelation in panel data \\
\hline $\mathrm{F}(1,4)=0.363$ \\
\hline Prob $>\mathrm{F}=0.5792$ \\
\hline
\end{tabular}

Source: own processing using Stata 
Since the associated probability of this test is 0.57 , greater than 0.05 , we cannot reject the null hypothesis and we conclude that the data used does not have first-order autocorrelation. The autocorrelation may cause smaller standard errors of the coefficients than they actually are and can cause a higher value of R-squared.

\subsection{Economic interpretation}

The econometric analysis were judged and interpreted based on the methodologies and indications of Baltagi (2005), Torres-Reyna (2007) and Wooldridge (2010).

In terms of economic interpretation, the coefficients obtained within the RE model indicates us the following:

- $\quad$ The impact of CIT: One percentage point increase in CIT revenues leads to an increase by 0.05 percentage points of GDP per capita, provided that the other independent variables are constant. The small value of this coefficient can indicate that the taxation of corporations has a limited impact on economic growth. However, under the RE model CIT is not significant from a statistical point of view;

- $\quad$ The impact of PIT: One percentage point increase in PIT revenues leads to an increase by 0.25 percentage points of GDP per capita, provided that the other independent variables are constant. The direct positive relationship between PIT and GDP per capita might be seen in the sense that, in the case where PIT revenues are higher, consequently the revenues of the citizens are higher. Another way of interpreting this coefficient is that PIT might be less harmful to economic growth;

- $\quad$ The impact of VAT: One percentage point increase in VAT revenues leads to an increase by 0.38 percentage points of GDP per capita, provided that the other independent variables are constant. This high value of the coefficient could easily be perceive in the way that the economies from the former Communist Bloc are consumption-based economies. In this case, one can argue that consumption leads to economic growth for the citizens of these countries.

The results obtained in this paper largely follow the last trend of the results found in the recent literature. This study represents a contribution to the literature with a specific analysis on the countries from the former Communist Bloc and conclusive economic and economtric results.

\section{Conclusions}

Through this paper, we analysed the impact of the main elements of taxation on the economic growth felt at the population level (GDP per capita as proxy) in the case of countries from the former Communist Bloc that are currently EU Member States.

According to the econometric tests performed, we reached to an econometric model with random effects that assumes the fact that the variation across countries are random and uncorrelated with the predictor or with the independent variables. The model obtained showed a positive direct relationship between all the tax elements included and the GDP per capita. However, from a statistical point of view, CIT is not significant.

It is self-evident that the economic development is affected by numerous factors, but the analysis carried out in this paper focused only on the fiscal elements, which only represent a part of these factors.

On the specific case of PIT, even though the related result is not in agreement with most of the studies found in the specialized literature, our result is still aligned with the ones obtained by Stoilova \& Patonov (2012) and Surugiu \& Surugiu (2018b) that showed a positive influence of PIT on the economic growth. 
Further, in terms of econometric analysis, by extending the comparison, similar results were found at the level of Eastern Europe countries and the developed European Countries by Vatavu et al. (2019).

The positive relationship between PIT and GDP per capita is also aligned with the results obtained by Andrašić et al. (2019) at the level of 35 OECD countries. In comparison, in our analysis, the impact of PIT is statistically significant, but the impact of CIT is not.

Therefore, one can argue that the countries from the former Communist Bloc used the taxation in a positive way and succeeded to sustain their economic development through the tools of taxation.

In general, the results are consistent with the specialized literature. This paper represents a contribution to the literature through an analysis of the effects of taxation elements on economic growth at a specific level, namely at the level of the countries from the former Communist Bloc that are currently EU Member States.

\section{References}

Alfò, M., Carbonari, L., \& Trovato, G., 2020. On the Effects of Taxation on Growth: an Empirical Assessment. CEIS Tor Vergata - Research Paper Series, Vol. 18, Issue 1, No. 480 - May 2020; http://dx.doi.org/10.2139/ssrn.3596116.

Andrašić, J., Kalaš, B., Mirović, V., Milenković, N., \& Pjanić, M., 2018. Econometric Modelling of Tax Impact on Economic Growth: Panel Evidence from OECD Countries. Economic Computation \& Economic Cybernetics Studies \& Research, 52(4).

Bakari, S., Ahmadi, A., \& Tiba, S., 2019. The Nexus among Domestic Investment, Taxation, and Economic Growth in Germany: Cointegration and Vector Error Correction Model Analysis. MPRA Paper, no. 96655.

Baltagi, B.H., 2005. Econometric analysis of panel data. 3rd edition. John Wiley\&Sons Ltd.; Bazgan, R. M., 2018. The impact of direct and indirect taxes on economic growth: An empirical analysis related to Romania. Proceedings of the 12th International Conference on Business Excellence 2018, 114-127; https://doi.org/10.2478/picbe-2018-0012.

Dackenhag, M., \& Hansson, A., 2012. Taxation of income and economic growth: An empirical analysis of 25 rich OECD countries. Working papers 2012:6. Department of Economics and Management - Lund University.

Dolenc, P, \& Laporsek, S., 2010. Tax wedge on labour and its effect on employment growth in the European Union. Prague Economic Papers, no. 4, 344-358; http://pep.vse.cz/doi/10.18267/i.pep.381.html.

Durovic-Todorovic, J., Milenkovic, I., \& Kalas, B., 2019. The relationship between direct taxes and economic growth in OECD countries. Economic Themes (2019) 57(3). 273-286; Eurostat, Database, 2020 [online], available at:

https://ec.europa.eu/eurostat/data/database [accessed 20.02.2020].

Hakim, T. A., 2020. Direct Versus Indirect Taxes: Impact on Economic Growth and Total Tax Revenue. International Journal of Financial Research. Vol. 11, no. 2.

Kalaš, B., Mirović, V., \& Milenković, N., 2018. The relationship between taxes and economic growth: Evidence from Serbia and Croatia. The European Journal of Applied Economics, 15(2), 17-28; https://doi.org/10.5937/EJAE15-18056.

Lymonova, E., 2019. Estimation of the effect of taxes and gross fixed capital formation on economic growth of Euro area. ЗАСНОВНИК । ВИДАВЕЦЬ: УНІВЕРСИТЕТ імені АЛЬФРЕДА НОБЕЛЯ, 5.

Stoilova, D., \& Patonov, N., 2012. An empirical evidence for the impact of taxation on economy growth in the European Union. Book of Proceeding-Tourism and Management Studies International Conference Algarve, Vol. 3. ESGT University of the Algarve, Portugal. 
Surugiu, M.R., \& Surugiu, C., 2018a. Fiscal variables and economic growth. Measuring the impact for Romania. EuroEconomica - Fiscal Theory and Practice, 1(37)/2018, 7-16.

Surugiu, M.R., \& Surugiu, C., 2018b. The assessment of taxation impact on economic development. A case study of Romania (1995-2014). EuroEconomica - Business Administration and Business Economics, 2(36)/2017, 7-20.

Szarowská, I., 2013. Effects of taxation by economic functions on economic growth in the European Union. Proceedings of the 6th International Scientific Conference: Finance and the performance of Firms in Science, Education and Practice. Tomas Bata University, 746758.

Topal, M. H., 2019. An Analysis of the Relationship between Tax Structure and Gross Domestic Product in European Transition Economies. JETAS, vol. 7-2 (2019).

Torres-Reyna, O., 2007. Panel data analysis fixed and random effects using Stata (v. 4.2). Data \& Statistical Services, Princeton University, 112.

Vatavu, S., Lobont, O. R., Stefea, P., \& Brindescu-Olariu, D., 2019. How Taxes Relate to Potential Welfare Gain and Appreciable Economic Growth. Sustainability, 11(15), 4094; https://doi.org/10.3390/su11154094.

Wooldridge, J. M., 2010. Econometric analysis of cross section and panel data. MIT press.

\section{Bio-note}

Andrei lonut Husman is a PhD student at the Bucharest University of Economic Studies, Finance Doctoral School, and currently he is working on PhD thesis: "Theoretical and empirical approaches on progressive versus proportional taxation dilemma". 